\title{
Special aspects of hemo-dynamic and reaction of erythrocytes in blood to standard physical load of different qualification female volleyball players
}

\author{
Popel' S. L., Tsap I.G., Yatciv Ya. N., Lapkovsky E. Yi., Synitsya A.V., Pyatnichuk D.V. \\ Vasyl Stefanyk Precarpathian National University, Ukraine
}

\begin{abstract}
Purpose:

to study the aspects of organism's cardio-hemo-dynamic and blood erythrocytes reaction of female volleyball players to standard physical load.

Material: $\quad$ with functional methods we studied cardio-hemo-dynamic and with the help of scanning electronic microscopy - erythrocytes' structure in 18 female volleyball players of different qualification (age $-22.0 \pm 0.60$ years).

Results: $\quad$ it was found that maximal physical load causes substantial changes in cardio-hemo-dynamic, which depend on female volleyball players' qualification. These changes have intrinsic to them type of blood circulation system reacting, which is manifested in the following: appropriate changes of some indicators; natural changes of periphery blood erythrocytes. In the article possible mechanisms of realization of female volleyball players' organism's typological features, depending on blood circulation type and erythrocytes' conformation, are discussed.

Conclusions: In relaxed state all female volleyball players have non-uniform cardio-hemo-dynamic of blood circulation. With hyper-dynamic blood circulation type, higher indicators of strike and minute blood volume were observed. With hypo-kinetic blood circulation type the opposite picture was observed: indicators of strike and minute blood volume, heart index, load on cardio-vascular system in different periods of day were low.

Keywords: female volleyball players, blood circulation, heart index, physical load, erythrocytes.
\end{abstract}

\section{Introduction}

The level of human organism's responding to physical load illustrates health condition and ability to sustain workability in professional functioning. For such assessment different approaches are used, selection of which depends on category of population. For assessment of students' reaction to physical load appropriate tests for motor activity are used [24, 50]. The tests application facilitates the following: optimization of physical loads $[19,30]$; correction of training process [37, 52]; improvement of motor skills [29, 41]; proper organization of pedagogic control [28, 36].

For determination of athletes' reaction to physical loads other approaches are used. Their aim is finding of the following: level of motivation to sports practicing $[16,43]$; successfulness in sports [20, 31]; individual approaches to training [22, 25]; working out of training models [21, 27].

Among such approaches proper place is taken by tests, based on finding of cardio-hemo-dynamic indicators. Such approaches are frequently used in sports. It permits to find athletes' reaction to physical loads and correct the process of preparation for competitions.

By the range of heart index (HI) oscillations central cardio-haemo-dynamic (CHD) is divided into hypokinetic (HK), eukinetic (EK) and hyper-kinetic (HrK) types of blood circulation. They are variants of hemodynamic norm [1, 3, 5].

Physical load of maximal intensity $\left(\mathrm{PL}_{\max }\right)$ can result in CHD changes and create pre-conditions for disorder

\footnotetext{
(c) Popel' S. L., Tsap I.G., Yatciv Ya. N., Lapkovsky E. Yi. Synitsya A.V., Pyatnichuk D.V., 2017
} doi:10.15561/18189172.2017.0508 of erythrocyte homeostasis $[4,12,13]$. With it, CHD has definite typological features and depends on quickness of system blood circulation's reacting. In such case changes of periphery blood erythrocytes (EPB) with $\mathrm{PL}_{\max }$ are determined by bio-chemical reactions. Such reactions lead to reduction of acid/alkaline balance. In its turn, acidosis causes deformation of EPB [46].

Reactions of athletes' organisms to maximal and standard physical loads are shown in the following directions:

- Study of blood bio-chemical indicators and their influence on health of 100 meters' runners [33];

- Finding of energy supply mechanisms of athletes' high workability by blood bio-chemical indicators [17];

- Finding of physical effects of football referees' workability by lactate content in blood [18];

- Quantitative assessment of training load in team kinds of sports (testing on run track for quickness and lactate concentration in blood). The authors found that individualized impulse training can be used for improvement of aerobic indicators in competition season [45];

- Distribution of professional mini-football athletes' load. The research of blood bio-chemical indicators permitted to find mechanisms of physical workability improvement [48];

Adaptation to physical loads permitted to determine:

- Mechanisms of muscular strength and muscular mass age reduction, connected with chronic inflammation. Physical activity causes anti-inflammation effect, but it is modulated by additional factors [26];

- Regular physical exercises facilitate reduction 
of oxidation stress and cause some changes in metabolism of iron. These changes were connected with reduction of blood ferritine. The authors offer the program of Nordic walking (12 weeks, thrice a week) [38];

- Nordic Walking reduces resistance to insulin [40];

- Nordic Walking significantly reduces ferritine concentration in blood that explains the registered reduction of iron in organism [39].

As some specialists point non uniformity of CHD types is conditioned by body constitution and is a physiological norm of health [2, 6, 9]. Study of EPB changes with $\mathrm{PL}_{\max }$, depending on CHD type is still out of scientists' attention. Which correlations of different EPB conformation forms are in athletes with different blood circulation hemodynamic type has not been clear $[2,13]$. The data of some authors point at same type of organism's reaction to $\mathrm{PL}_{\max }$ in people with hypo and hypertonic blood circulation type [1, 2, 3]. By the data of other authors [7, 8] - prevails one of them $[4,7,10]$. The question about role of EPB in origin of such reactions is still unsolved [8, 11, 13]. Studies of CHD types in children resulted in idea that they are genetically determined [12]. But not equal percentage of these types in different age groups contradicts to it $[3,9,14]$. With it, the question about special aspects of CHD and EPB reactions to single standard physical load, depending on athletes' sportsmanship and CHD type still remains to be out of specialists' attention [6, 8].

Hypothesis: it was assumed that athletes with different CHD type have different organism's sensitivity to standard physical load, that is manifested as different conformative EPB changes..

The purpose of the work is to study the aspects of organism's cardio-hemo-dynamic and blood erythrocytes reaction of female volleyball players to standard physical load, depending on qualification level.

\section{Material and methods}

Participants: 18 girl students of $20.0 \pm 0.6$ yrs age, who practiced volleyball, participated in the research. Depending on girl students' qualification, they were divided into two groups. First group consisted of 11 girl students, who attend volleyball training, but have no sport category. Group 2 included female volleyball players of supreme league team (masters of sports) - members of team of Vasyl Stefanyk Precarpathian National University.

Organization of the research: application of $\mathrm{PL}_{\text {max }}$ of $3.5 \mathrm{~W} / \mathrm{kg}$ of body mass is the most optimal methodic for ergo metric testing (ET) of different age athletes' physical workability [12-14]. For determination of CHD indicators we used ergo meter Kettler (Germany) and computer diagnostic complex "CardioLab+". Cardio-hemodynamic mechanisms of short term adaptation to $\mathrm{PL}_{\text {max }}$ we assessed by indicators HI; systolic (SBP) and diastolic (DBP) blood pressure; average blood pressure (ABP). By changes of heart beats rate we found: stroke blood output (SBO); minute blood output (MBO). By value of load on cardio-vascular system in different periods of day (PD) we determined energetic characteristics of heart functioning and myocardium demands in oxygen [14]. It is calculated by formula: $\mathrm{PD}=(\mathrm{BP} . \mathrm{HBR}) / 100$, where $\mathrm{BP}$ is blood pressure and HBR - heart beats rate.

For studying erythrocytes' conformation and biochemical characteristics we took capillary blood by protocol of determination of glucose concentration in blood plasma. Taking of material was fulfilled just before $\mathrm{PL}_{\max }$ and after 1-3 minutes of recreation period. Concentration of hemoglobin was tested by standard method. The quantity of erythrocytes was tested by unified method of calculation in Goryaiev's chamber. Hematocrit was found by micro-method with application of standard heparinizied capillaries. Morphological studies of erythrocytes were carried out with the help of scanning electronic microscope «JEOL-25M-T220A» (Japan) by commonly accepted methodic [23]. All studies were fulfilled at the end of academic year.

Statistical analysis: the received quantitative indicators were processed with the help of STATISTICA 6,0 program.

\section{Results}

The studies showed that in relaxed state volleyball players of both groups (see tables 1,2 ) have non uniform CHD different types.

Typological analysis $[2,9,11]$ showed that $42 \%$ of the tested female volleyball players have hypo-kinetic, 31\%eukinetic and $27 \%$ - hyper-kinetic type of CHD.

In volleyball players of $2^{\text {nd }}$ group with HrBC type we observed confidently higher indicators of HBR, SBO, $\mathrm{MBO}, \mathrm{HI}$ and PD $(\mathrm{p}<0.05)$. In case of HBC type initial values were the lowest. EBC indicators were at average level. In relaxed state, in $2^{\text {nd }}$ group female volleyball players with $\mathrm{HrBC}$ type indicators SBO, MBO and $\mathrm{HI}$ were high $(\mathrm{p}<0.05)$ and PD indicator was low. In relaxed state PD indicator took intermediate position between hyper and hypo-kinetic types of CHD.

$\mathrm{PL}_{\max }$ was followed by changes in hemo-dynamic of different expressiveness. These changes have certain typological specificities of blood circulation's reacting. In tables 1 and 2 we can see that $\mathrm{PL}_{\max }$ from the first minute causes noticeable increase of SBP in both groups' volleyball players with different CHD. ABP is substantially changed after first minute of load. HBR became maximal up to the end of the fifth minute of $\mathrm{PL}_{\max }$. HBR increased depending on CHD: accordingly, 2.27; 2.18 and 2.14 times $(\mathrm{P}<0.05)$. Concerning $1^{\text {st }}$ group volleyball players with he same reactions of blood circulation to $\mathrm{PL}_{\max }$, their HBR was the lowest (accordingly by $9.26 \%, 10.38 \%$ and $14.77 \%$; $<<0.05)$.

Thus, increase of SBP under $\mathrm{PL}_{\max }$ in $1^{\text {st }}$ group took place at the account of SBO increasing. It is known that increase of SBO results in reciprocal inhibition of sinus node automation. It reduces HBR [3, 9]. It is observed in $1^{\text {st }}$ groups volleyball players with blood circulation of different type.

$\mathrm{PL}_{\max }$ in $1^{\text {st }}$ group volleyball players with $\mathrm{HrBC}$ causes insignificant (in average by $5.3 \pm 0.11 \%, \mathrm{P}<0.05$ ) increase of EPB. In $2^{\text {nd }}$ group there happens statistically significant 
Table 1. Indicators of different types of cardio-hemo-dynamic of $1^{\text {st }}$ group's volleyball players before and after standard physical load and in recreation period $(M \pm m, n=7)$

\begin{tabular}{|c|c|c|c|c|c|c|c|}
\hline \multirow{2}{*}{ Indicators } & \multirow{2}{*}{$\begin{array}{l}\text { Blood } \\
\text { circulation } \\
\text { type }\end{array}$} & \multirow{2}{*}{$\begin{array}{l}\text { Relaxed } \\
\text { state }\end{array}$} & \multicolumn{2}{|c|}{ Duration of physical load } & \multirow[b]{2}{*}{$5 \mathrm{~min}$} & \multicolumn{2}{|c|}{ Recreation time } \\
\hline & & & $1 \mathrm{~min}$ & $3 \mathrm{~min}$ & & $5 \mathrm{~min}$ & $10 \mathrm{~min}$ \\
\hline \multirow{3}{*}{ HBR, bpm } & $\mathrm{HBC}$ & $71,8 \pm 2,3$ & $118,3 \pm 2,8^{*}$ & $144,8 \pm 3,4^{*}$ & $150,1 \pm 4,8^{*}$ & $108,3 \pm 4,2^{*}$ & $89,1 \pm 3,2$ \\
\hline & EBC & $75,8 \pm 2,5$ & $120,7 \pm 2,6^{*}$ & $149,0 \pm 3,2^{*}$ & $152,1 \pm 4,5^{*}$ & $115,9 \pm 4,3^{*}$ & $94,8 \pm 2,1$ \\
\hline & $\mathrm{HrBC}$ & $85,0 \pm 3,1$ & $124,0 \pm 3,4^{*}$ & $134,4 \pm 4,1^{*}$ & $147,5 \pm 4,4^{*}$ & $114,0 \pm 3,1^{*}$ & $95,0 \pm 2,6$ \\
\hline \multirow{3}{*}{$\begin{array}{l}\text { SBP, mm/ } \\
\text { merc.col }\end{array}$} & $\mathrm{HBC}$ & $117,0 \pm 3,2$ & $144,0 \pm 3,2 *$ & $158,1 \pm 4,3^{*}$ & $170,1 \pm 5,2^{*}$ & $135,1 \pm 4,2^{*}$ & $116,9 \pm 3,2$ \\
\hline & EBC & $118,0 \pm 2,1$ & $151,9 \pm 2,9 *$ & $164,4 \pm 3,2^{*}$ & $178,9 \pm 4,3^{*}$ & $134,0 \pm 3,7^{*}$ & $120,1 \pm 4,7$ \\
\hline & $\mathrm{HrBC}$ & $126,0 \pm 1,1$ & $160,6 \pm 2,6^{*}$ & $168,0 \pm 3,3 *$ & $179,0 \pm 4,6^{*}$ & $139,0 \pm 3,4^{*}$ & $123,2 \pm 3,6$ \\
\hline \multirow{3}{*}{$\begin{array}{l}\mathrm{DBP}, \mathrm{mm} / \\
\text { merc.col }\end{array}$} & $\mathrm{HBC}$ & $60,0 \pm 1,2$ & $65,0 \pm 1,4$ & $72,0 \pm 2,1$ & $76,0 \pm 1,4$ & $73,0 \pm 1,6$ & $70,1 \pm 1,2$ \\
\hline & $\mathrm{EBC}$ & $65,0 \pm 1,4$ & $70,0 \pm 1,7$ & $73,0 \pm 1,4$ & $74,0 \pm 1,2$ & $68,0 \pm 1,1$ & $67,3 \pm 1,6$ \\
\hline & $\mathrm{HrBC}$ & $67,0 \pm 1,2$ & $68,0 \pm 1,1$ & $74,0 \pm 1,5$ & $77,0 \pm 1,9$ & $68,0 \pm 1,6$ & $66,0 \pm 1,1$ \\
\hline \multirow{3}{*}{$\begin{array}{l}\text { ABP mm/ } \\
\text { merc.col }\end{array}$} & $\mathrm{HBC}$ & $88,5 \pm 3,4$ & $106,5 \pm 4,1^{*}$ & $115,0 \pm 4,5^{*}$ & $123,1 \pm 4,5^{*}$ & $104,2 \pm 3,2 *$ & $93,5 \pm 2,3$ \\
\hline & EBC & $91,5, \pm 2,3$ & $111,2 \pm 3,3^{*}$ & $118,7 \pm 3,6 *$ & $126,3 \pm 5,9 *$ & $101,0 \pm 4,3^{*}$ & $93,7 \pm 2,6$ \\
\hline & $\mathrm{HrBC}$ & $96,0 \pm 2,1$ & $114,3 \pm 4,2^{*}$ & $121,0 \pm 3,3^{*}$ & $128,0 \pm 5,4^{*}$ & $103,5 \pm 3,8$ & $94,6 \pm 2,1$ \\
\hline \multirow{3}{*}{ SBO, ml } & $\mathrm{HBC}$ & $49,9 \pm 1,6$ & $75,0 \pm 3,5^{*}$ & $77,1 \pm 3,9 *$ & $86,0 \pm 2,8^{*}$ & $58,1 \pm 2,1$ & $48,8 \pm 2,6$ \\
\hline & EBC & $64,1 \pm 2,1$ & $90,1 \pm 2,5^{*}$ & $91,1 \pm 3,2 *$ & $93,2 \pm 3,3 *$ & $69,2 \pm 2,3$ & $63,1 \pm 2,1$ \\
\hline & $\mathrm{HrBC}$ & $78,9 \pm 1,4$ & $93,0 \pm 2,3 *$ & $96,1 \pm 2,3 *$ & $96,9 \pm 2,1^{*}$ & $92,3 \pm 3,3 *$ & $86,1 \pm 2,2$ \\
\hline \multirow{3}{*}{ MBO, I } & $\mathrm{HBC}$ & $4,2 \pm 0,4$ & $6,4 \pm 0,5^{*}$ & $7,7 \pm 0,9 *$ & $8,5 \pm 1,2 *$ & $5,6 \pm 0,3^{*}$ & $4,6 \pm 0,5$ \\
\hline & $\mathrm{EBC}$ & $5,3 \pm 0,3$ & $7,8 \pm 0,4^{*}$ & $8,7 \pm 1,1^{*}$ & $10,2 \pm 1,8^{*}$ & $6,7 \pm 0,4^{*}$ & $5,3 \pm 0,5$ \\
\hline & $\mathrm{HrBC}$ & $7,2 \pm 0,4$ & $10,6 \pm 0,7^{*}$ & $11,9 \pm 1,4^{*}$ & $12,9 \pm 2,1^{*}$ & $8,8 \pm 0,9$ & $7,2 \pm 0,6$ \\
\hline \multirow{3}{*}{$\mathrm{HI}, \mathrm{I} / \mathrm{min} / \mathrm{m}$} & $\mathrm{HBC}$ & $2,2 \pm 0,1$ & $4,8 \pm 0,3 *$ & $4,9 \pm 0,4 *$ & $6,8 \pm 0,3 *$ & $3,3 \pm 0,2 *$ & $2,8 \pm 0,1$ \\
\hline & $\mathrm{EBC}$ & $3,4 \pm 0,2$ & $5,2 \pm 0,4^{*}$ & $7,0 \pm 0,6 *$ & $7,8 \pm 0,4^{*}$ & $4,1 \pm 0,4^{*}$ & $3,5 \pm 0,2$ \\
\hline & $\mathrm{HrBC}$ & $4,3 \pm 0,4$ & $7,8 \pm 0,6^{*}$ & $8,1 \pm 0,8^{*}$ & $8,6 \pm 0,7^{*}$ & $4,8 \pm 0,5$ & $4,1 \pm 0,5$ \\
\hline \multirow{3}{*}{ PD, conv.un. } & $\mathrm{HBC}$ & $79,8 \pm 2,2$ & $150,7 \pm 8,3^{*}$ & $209,4 \pm 10,2 *$ & $223,9 \pm 11,1^{*}$ & $140,9 \pm 12,7^{*}$ & $82,0 \pm 6,2$ \\
\hline & EBC & $88,9 \pm 2,7$ & $201,7 \pm 9,6 *$ & $233,9 \pm 11,2 *$ & $245,4 \pm 14,2^{*}$ & $145,1 \pm 15,6^{*}$ & $91,1 \pm 6,7$ \\
\hline & $\mathrm{HrBC}$ & $109,9 \pm 3,2$ & $211,8 \pm 10,2^{*}$ & $244,3 \pm 12,3^{*}$ & $252,7 \pm 15,6^{*}$ & $166,3 \pm 16,1^{*}$ & $106,4 \pm 6,8$ \\
\hline
\end{tabular}

Notes: 1) HBC - hypokinetic blood circulation; EBC - eukinetic blood circulation; HrBC - hyperkinetic blood circulation; $2)^{*}$-difference is confident at $p<0.05$. Absence of mark means that difference is not confident. In all cases confidence was found in comparison with relaxed state.

increase of EPB. It is facilitated by hemo-concentration (15\% volleyball players with $\mathrm{HBC}$ ). In $85 \%$ girl students with EBC it causes reduction of their quantity. It is conditioned by destructive influence of factors, which accompany muscular activity. It is observed with weakening of cardio-respiratory system's adaptation potentials. They are: increased blood circulation; rising of temperature and acidosis [21].

In contrast to $1^{\text {st }}$ group (see fig. 1a) in $2^{\text {nd }}$ group's volleyball players with HBC there appear some reversibly changed forms of EPB (see fig. 1b). In girls students with EBC erythrocytes remain unchanged after $\mathrm{PL}_{\max }$ (see fig. 2a, b). Fig.1 Structural reconstruction of periphery blood erythrocytes in $1^{\text {st }}$ (a) and 2 (b) groups' volleyball players with hypo-kinetic hemo-dynamic type after single maximal physical load. Legend: 1 - normal forms of erythrocytes; 2 - reversibly changed forms of erythrocytes; 3 - irreversibly changed forms of erythrocytes. The method is - scanning electronic microscopy, scale: 1500:1.

In $2^{\text {nd }}$ group's volleyball players with $\mathrm{HrBC}$ we observed increase of EPB aggregation ability (content of aggregates increased by $15 \%$ ) and increase of coefficient of their deformation (by $18 \%$ ). It is a result of muscular work (see fig. 3).

\section{Discussion}

The conducted earlier studies showed [11, 53], that at the end of academic year female volleyball players of $2^{\text {nd }}$ group have low level of functional reserves. It requires more careful attention of different specialization scientists to students' physical condition, who practice intensive trainings in parallel to main studies.

PL of different intensity plays great role in formation of organism's general endurance. Such endurance is especially required for the following: in different competitions; in trainings; in everyday life of studentsathletes [42, 53]. In such case EPB is a convenient object for such researches: they participate in processes, connected with sustaining of the whole organism's homeostasis [34, 44, 49]. In our research we found that in $57 \%$ of $2^{\text {nd }}$ group's volleyball players, under influence of $\mathrm{PL}_{\max }$ negative morphological changes of EPB appear. It is conditioned by dis-metabolic disorders. The basis 
Table 2. Cardio-hemo-dynamic indicators of $2^{\text {nd }}$ group's volleyball players with different blood circulation type before physical load and in recreation period $(M \pm m, n=11)$

\begin{tabular}{|c|c|c|c|c|c|c|c|}
\hline \multirow{2}{*}{ Indicators } & \multirow{2}{*}{$\begin{array}{l}\text { Blood } \\
\text { circulation } \\
\text { type }\end{array}$} & \multirow{2}{*}{$\begin{array}{l}\text { Relaxed } \\
\text { state }\end{array}$} & \multicolumn{2}{|c|}{ Duration of physical load } & \multirow[b]{2}{*}{$5 \mathrm{~min}$} & \multicolumn{2}{|c|}{ Recreation time } \\
\hline & & & $1 \mathrm{~min}$ & $3 \mathrm{~min}$ & & $5 \mathrm{~min}$ & $10 \mathrm{~min}$ \\
\hline \multirow{3}{*}{ HBR, bpm } & $\mathrm{HBC}$ & $72,1 \pm 2,3$ & $122,9 \pm 2,1^{*}$ & $145,5 \pm 2,7^{*}$ & $164,0 \pm 3,6^{*}$ & $102,8 \pm 3,3^{*}$ & $80,0 \pm 1,2$ \\
\hline & EBC & $77,0 \pm 2,2$ & $122,3 \pm 2,4^{*}$ & $148,1 \pm 5,0 *$ & $167,9 \pm 4,1^{*}$ & $103,0 \pm 3,7^{*}$ & $81,9 \pm 2,3$ \\
\hline & $\mathrm{HrBC}$ & $79,3 \pm 2,5$ & $140,9 \pm 2,3^{*}$ & $153,2 \pm 3,1^{*}$ & $169,3 \pm 4,3^{*}$ & $104,5 \pm 3,1^{*}$ & $83,4 \pm 2,2$ \\
\hline \multirow{3}{*}{$\begin{array}{l}\text { SBP, mm/ } \\
\text { merc.col }\end{array}$} & $\mathrm{HBC}$ & $107,8 \pm 2,3$ & $136,4 \pm 3,1^{*}$ & $151,0 \pm 3,3^{*}$ & $153,1 \pm 4,1^{*}$ & $122,2 \pm 2,1$ & $112,1 \pm 3,1$ \\
\hline & EBC & $111,8 \pm 2,1$ & $140,2 \pm 3,8^{*}$ & $153,6 \pm 4,3^{*}$ & $156,1 \pm 4,6^{*}$ & $124,4 \pm 2,3$ & $112,9 \pm 3,1$ \\
\hline & $\mathrm{HrBC}$ & $115,5 \pm 2,2$ & $143,2 \pm 3,0 *$ & $156,2 \pm 3,4^{*}$ & $169,5 \pm 4,9 *$ & $125,3 \pm 2,4$ & $114,3 \pm 3,2$ \\
\hline \multirow{3}{*}{$\begin{array}{l}\text { DBP, mm/ } \\
\text { merc.col }\end{array}$} & $\mathrm{HBC}$ & $65,2 \pm 3,1$ & $60,3 \pm 2,1$ & $61,1 \pm 2,2$ & $60,1 \pm 3,6$ & $65,1 \pm 3,8$ & $64,9 \pm 2,3$ \\
\hline & EBC & $69,8 \pm 2,2$ & $70,3 \pm 2,4$ & $71,6 \pm 3,9$ & $72,8 \pm 4,1$ & $65,9 \pm 3,1$ & $65,2 \pm 2,4$ \\
\hline & $\mathrm{HrBC}$ & $71,0 \pm 3,3$ & $74,6 \pm 4,1$ & $80,7 \pm 4,3$ & $86,2 \pm 4,5$ & $77,2 \pm 3,1$ & $73,3 \pm 2,4$ \\
\hline \multirow{3}{*}{$\begin{array}{l}\text { ABP mm/ } \\
\text { merc.col }\end{array}$} & $\mathrm{HBC}$ & $86,5 \pm 2,7$ & $98,4 \pm 2,6^{*}$ & $106,1 \pm 2,7^{*}$ & $106,6 \pm 3,8 *$ & $93,7 \pm 2,8^{*}$ & $88,5 \pm 2,8$ \\
\hline & EBC & $90,8 \pm 2,1$ & $105,3 \pm 3,1 *$ & $112,6 \pm 4,1^{*}$ & $114,5 \pm 4,4^{*}$ & $95,8 \pm 2,7^{*}$ & $89,5 \pm 2,8$ \\
\hline & $\mathrm{HrBC}$ & $93,3 \pm 2,7$ & $108,9 \pm 3,5^{*}$ & $118,5 \pm 3,9 *$ & $127,8 \pm 4,7^{*}$ & $101,2 \pm 3,8$ & $93,8 \pm 2,9$ \\
\hline \multirow{3}{*}{ SBO, ml } & $\mathrm{HBC}$ & $47,4 \pm 2,2$ & $67,8 \pm 3,1^{*}$ & $64,3 \pm 3,2 *$ & $63,8 \pm 2,9 *$ & $53,1 \pm 2,4$ & $45,1 \pm 2,3$ \\
\hline & EBC & $55,9 \pm 2,3$ & $78,9 \pm 2,3 *$ & $77,8 \pm 2,4 *$ & $75,9 \pm 2,3 *$ & $61,7 \pm 2,1^{*}$ & $55,8 \pm 1,9$ \\
\hline & $\mathrm{HrBC}$ & $72,1 \pm 2,3$ & $97,2 \pm 3,3 *$ & $90,1 \pm 3,1^{*}$ & $85,3 \pm 3,1^{*}$ & $86,1 \pm 3,1$ & $79,4 \pm 2,7$ \\
\hline \multirow{3}{*}{ MBO, I } & $\mathrm{HBC}$ & $3,9 \pm 0,3$ & $7,1 \pm 0,5^{*}$ & $8,2 \pm 0,3 *$ & $8,9 \pm 1,2 *$ & $5,2 \pm 0,4^{*}$ & $4,2 \pm 0,2$ \\
\hline & $\mathrm{EBC}$ & $4,8 \pm 0,5$ & $8,3 \pm 0,4^{*}$ & $8,7 \pm 0,6^{*}$ & $9,1 \pm 0,6^{*}$ & $6,5 \pm 0,3 *$ & $5,1 \pm 0,5$ \\
\hline & $\mathrm{HrBC}$ & $6,2 \pm 0,3$ & $9,7 \pm 0,5^{*}$ & $11,4 \pm 0,7^{*}$ & $11,9 \pm 0,9 *$ & $7,8 \pm 0,5^{*}$ & $6,7 \pm 0,4$ \\
\hline \multirow{3}{*}{$\mathrm{HI}, \mathrm{I} / \mathrm{min} / \mathrm{m}$} & $\mathrm{HBC}$ & $2,3 \pm 0,4$ & $4,2 \pm 0,3 *$ & $5,3 \pm 0,3^{*}$ & $6,5 \pm 0,4^{*}$ & $3,1 \pm 0,2$ & $2,4 \pm 0,1$ \\
\hline & EBC & $3,0 \pm 0,2$ & $5,4 \pm 0,5^{*}$ & $6,0 \pm 0,3 *$ & $7,1 \pm 0,4^{*}$ & $4,4 \pm 0,2$ & $3,1 \pm 0,3$ \\
\hline & $\mathrm{HrBC}$ & $3,9 \pm 0,5$ & $8,7 \pm 0,8^{*}$ & $8,9 \pm 0,5^{*}$ & $9,6 \pm 0,5^{*}$ & $5,2 \pm 0,4^{*}$ & $4,0 \pm 0,4$ \\
\hline \multirow{3}{*}{ PD, conv.un. } & $\mathrm{HBC}$ & $76,3 \pm 1,2$ & $167,9 \pm 12,3^{*}$ & $225,8 \pm 34,4^{*}$ & $228,6 \pm 33,7^{*}$ & $129,4 \pm 11,2^{*}$ & $89,9 \pm 5,4$ \\
\hline & $\mathrm{EBC}$ & $86,1 \pm 1,8$ & $180,7 \pm 15,1^{*}$ & $241,7 \pm 23,2^{*}$ & $240,8 \pm 28,1^{*}$ & $128,9 \pm 10,1^{*}$ & $89,5 \pm 5,5$ \\
\hline & $\mathrm{HrBC}$ & $99,6 \pm 3,6$ & $209,4 \pm 16,7^{*}$ & $248,9 \pm 24,3^{*}$ & $249,7 \pm 28,3^{*}$ & $125,9 \pm 8,3^{*}$ & $93,8 \pm 6,1$ \\
\hline
\end{tabular}

Notes: 1) HBC - hypokinetic blood circulation; EBC - eukinetic blood circulation; HrBC - hyperkinetic blood circulation; $2)^{*}$-difference is confident at $p<0.05$. Absence of mark means that difference is not confident. In all cases confidence was found in comparison with relaxed state.

of such changes is exhaustion of functional potentials of organism's bio-systems. It is facilitated by negative influence of combined increased mental and physical load during academic year [53].

The peculiarity of $2^{\text {nd }}$ group volleyball players' with HBC hemo-dynamic reacting to $\mathrm{PL}_{\max }$ was active involvement of mechanism of periphery blood circulation regulation mechanism in work. It increases local blood flow at the account of widening of working muscles' vessels.

The main mechanism of ABP sustaining for $\mathrm{HeBC}$ is high values of HI. They are determined by contracting ability of left ventricle with low values of total periphery resistance (TPR) of vessels.

Heart works in ineffective mode that is why its compensatory potentials are limited. For such type high activity of sympathetic-adrenaline system is characteristic. In case of HBC, in homeostasis sustaining tonus of hemo-vessels of blood systems artery part dominates. In our research we observed high TPR, but power of left ventricle's contraction is minimal [1, 3, 13]. This type of blood circulation is the least effective and has low adaptation potential [12, 47].

As a number of authors notes [2, 11, 13], organism of people with different blood circulation type reacts to $\mathrm{PL}_{\max }$ by increasing of $\mathrm{HI}$ : from hypo-kinetic to hyperkinetic type. Independent on group, in volleyball players with $\mathrm{HrBC}$ we observed the highest $\mathrm{HI}$ indicators under $\mathrm{PL}_{\max }$. However, comparing with relaxed state they increase only 1.79 times in $1^{\text {st }}$ group and 2.46 times in $2^{\text {nd }}$ group $(\mathrm{p}<0.05)$.

The received data show that in relaxed state, the presence of EBC and $\mathrm{HrBC}$ set high requirements to energy supply of heart functioning.

Intensive external heart work (especially in $1^{\text {st }}$ group's volleyball players with $\mathrm{HrBC}$ ) can be explained prevailing of SBP indicators, which is accompanied by increase of myocardium demand in oxygen [1, 3, 7]. With high myocardium demand in oxygen in $1^{\text {st }}$ group's volleyball players with HrBC the heart's work becomes more efficient. It is proved by the fact that in $2^{\text {nd }}$ group's girl students we observed higher absolute values of such indicators as: heart work; energy consumption for transportation of one liter of $\mathrm{MBO}$; power of left 


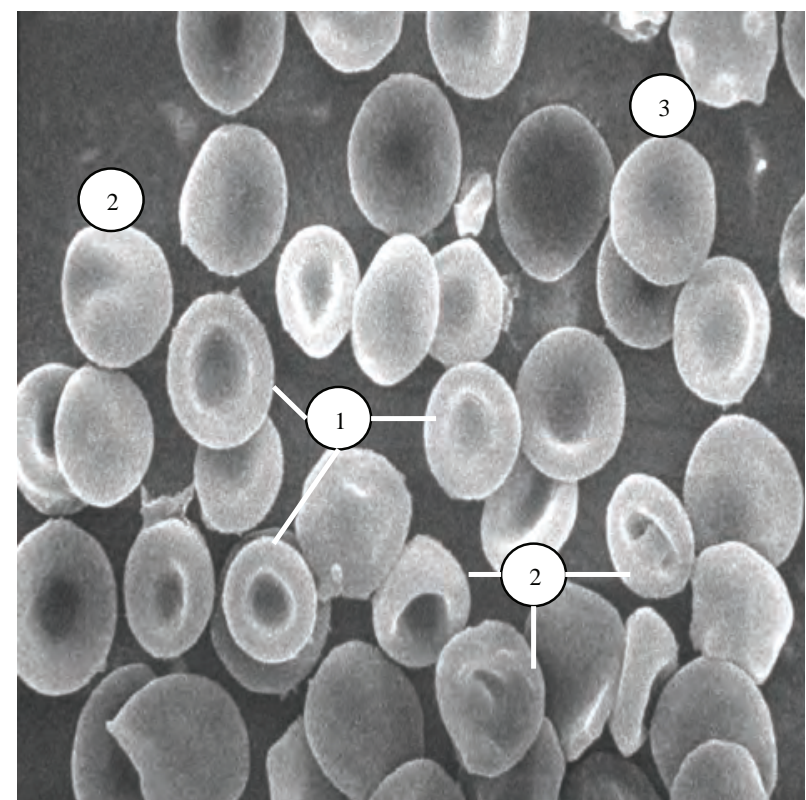

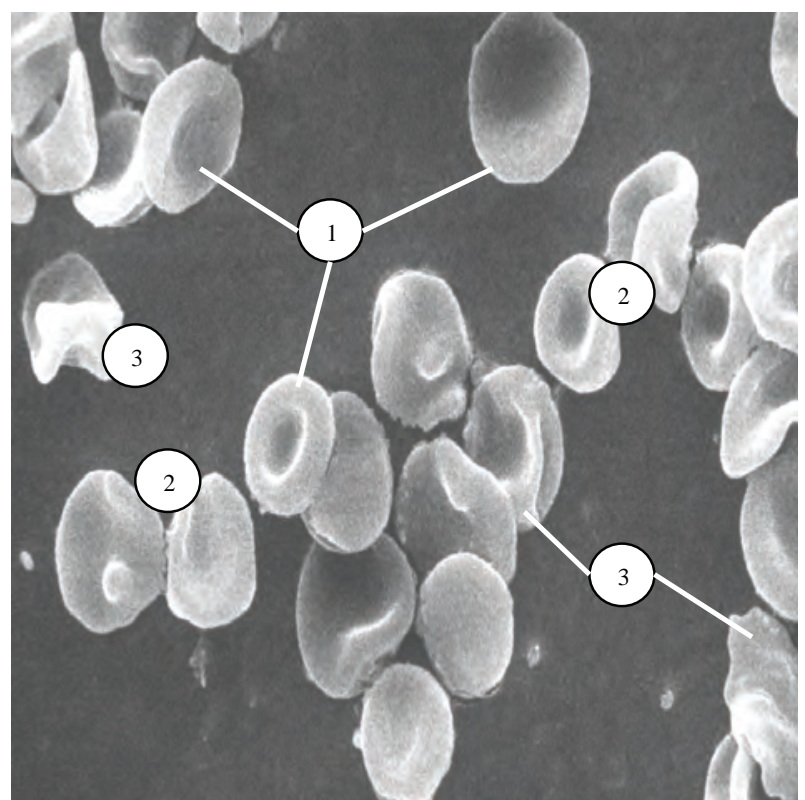

b

Fig.1 Structural reconstruction of periphery blood erythrocytes in 1st (a) and 2 (b) groups' volleyball players with hypo-kinetic hemo-dynamic type after single maximal physical load. Legend: 1 - normal forms of erythrocytes; 2 reversibly changed forms of erythrocytes; 3 - irreversibly changed forms of erythrocytes. The method is - scanning electronic microscopy, scale: 1500:1.

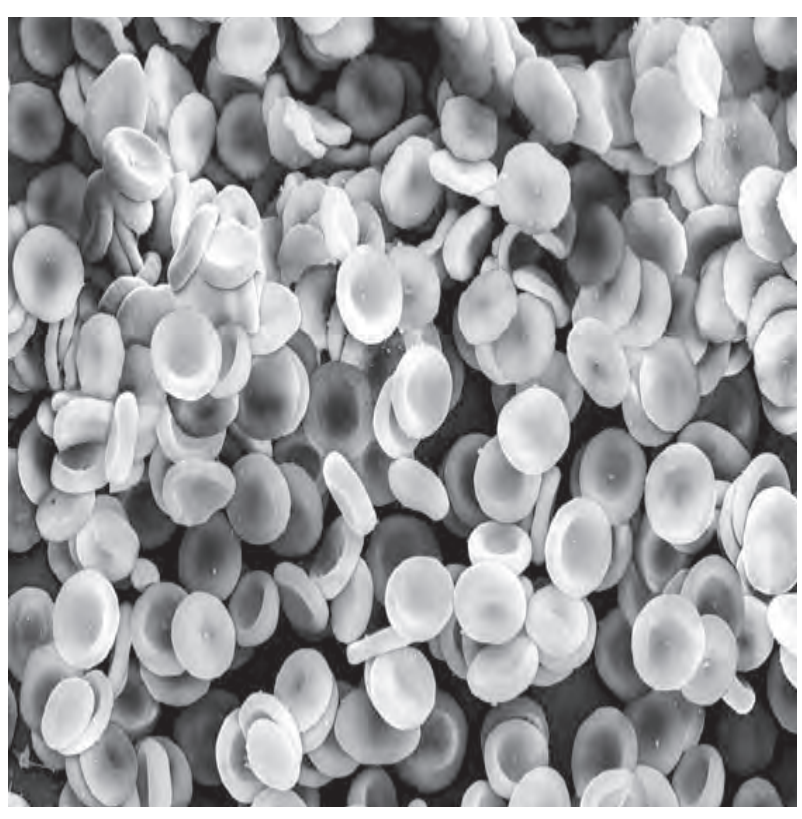

a

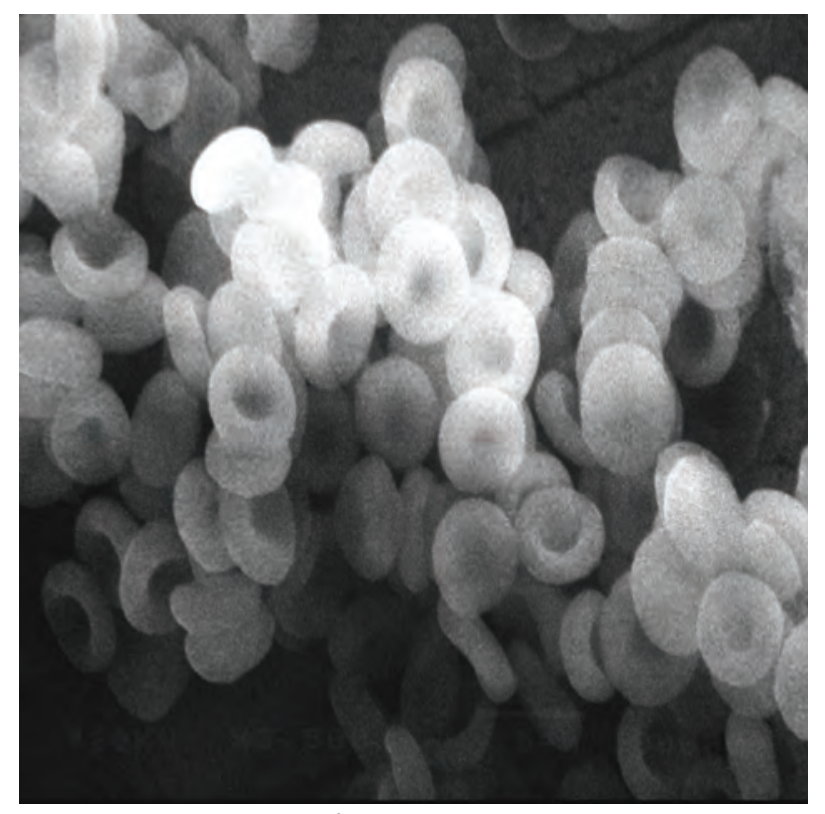

b

Fig. 2. The structure of periphery blood erythrocytes of $2^{\text {nd }}$ group's volleyball players with eukinetic blood circulation type after single maximal physical load. The method is - scanning electronic microscopy, scale: $a-1400: 1$ and b 1500:1.

ventricle's contraction and stroke output quickness.

Under such conditions damage of EPB structural wholeness appears. It facilitates their in-vessels' lysis and can result in progressing of anemia [46]. Such changes negatively influence on somatic health, sport efficiency and educational progress of students. It requires appropriate correction of educational and training process. Besides, it is necessary to liquidate negative after-effects. It is important to work out and use in due time adequate measures, directed at removal of possible pathological changes in organisms of students-athletes.

In opinion of some authors [49], EPB changes facilitate increase of viscosity of circulating blood. It will negatively influence on CHD type and saturation of tissues with oxygen. In the whole such bio-chemical and conformation changes of EPB are very unfavorable for realization of oxygen/transportation function of blood. They witness about insufficient organism's adaptation of 


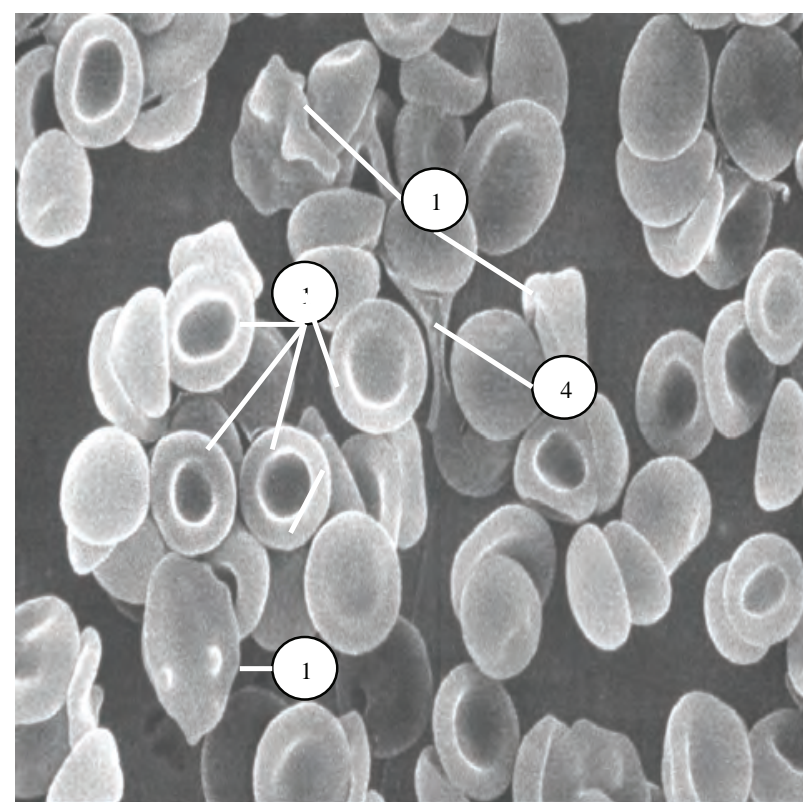

a

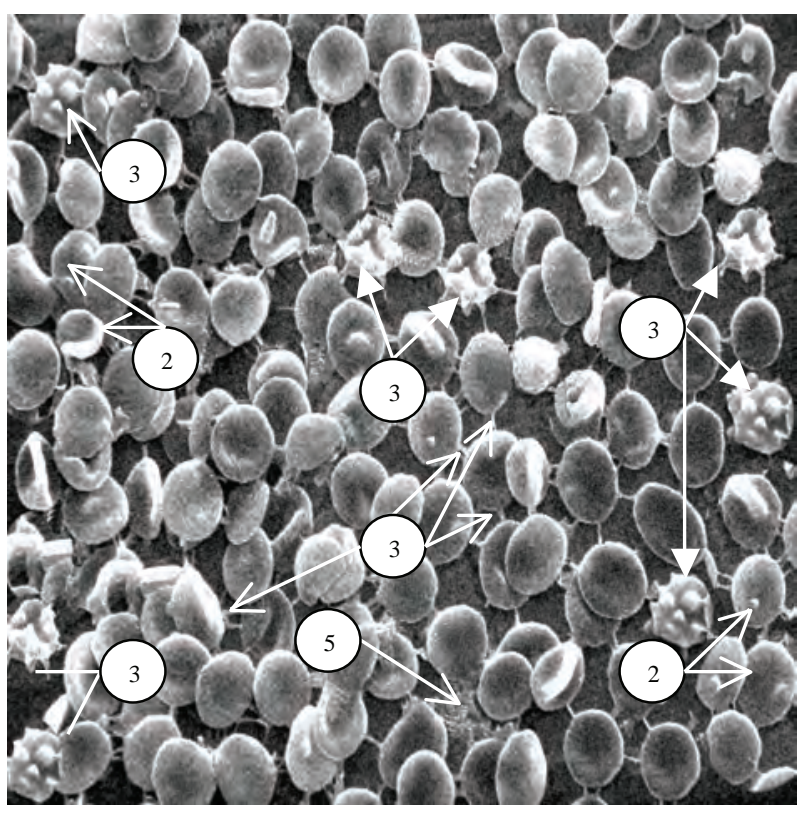

b

Fig. 3. Structural reconstruction of periphery blood erythrocytes in $1^{\text {st }}$ (a) and 2 (b) groups' volleyball players with hyper-kinetic hemo-dynamic type after single maximal physical load. Legend: 1 - normal forms of erythrocytes; 2 reversibly changed forms of erythrocytes; 3 - irreversibly changed forms of erythrocytes. 4 - "adhesion threads"; 5 - fibrin. The method is - scanning electronic microscopy, scale: a -1500:1; b - 1200:1.

$2^{\text {nd }}$ group's volleyball players (especially with $\mathrm{HrBC}$ to $\mathrm{PL}_{\max }$ at the end of academic year).

We have found interconnection between sportsmanship of volleyball players after $\mathrm{PL}_{\max }$ by CHD type. It points at demand in its value's gradation by quantitative-qualitative changes of EPB. Such approach can be used as a criterion for determination of adequate volume of training loads during academic year. It is in agreement with analogous criteria, found by other authors [32].

\section{Conclusions}

1. All tested female volleyball players in relaxed state demonstrate cardio-hemo-dynamic non uniformity of blood circulation. With hyper-kinetic blood circulation type we observed higher indicators of stroke and minute blood output and index of load on cardio-vascular system in different periods of day. With hypo-kinetic type of blood circulation's regulation we observed the opposite picture: indicators of stroke and minute output, heart index and load on cardio-vascular system in different periods of day were low.

2. In the process of $2^{\text {nd }}$ group's volleyball players' with HBC adaptation to maximal physical load we observed standard increase of stroke blood output already in the first minute of muscular functioning. With it periphery part of blood circulation's regulation was actively involved in work.
3. In case of eukinetic blood circulation type to larger extent cardio-hemo-dynamic reacting to maximal physical load manifested. In $1^{\text {st }}$ group's volleyball players' indicators of systolic blood pressure and load on cardiovascular system in different periods of day reached significant values. In $2^{\text {nd }}$ group's volleyball players indicators of minute blood output were higher. In $1^{\text {st }}$ group intensification of external work of heart was realized at the account of high systolic blood pressure. In $2^{\text {nd }}$ group it happened due to increase of minute blood output.

4. In $1^{\text {st }}$ group's volleyball players with hyper-kinetic blood circulation type, under maximal physical load we observed significant increase of systolic blood pressure and stroke blood output. In $2^{\text {nd }}$ group, since the $1^{\text {st }}$ minute stroke blood output increased noticeably. With it, in the work of periphery blood circulation's regulation we observed weakening of functional reserves. It was illustrated by increased quantity of deformed erythrocytes; by reduction of their size; increase of "adhesion threads" and small erythrocyte aggregates.

\section{Conflict of interests}

The authors declare that there is no conflict of interests. 


\section{References}

1. Andriychuk YN, Chyzhyk VV. The influence of the experimental procedure on the functional status of schoolchildren involved in the volleyball section. Pedagogics, psychology, medical-biological problems of physical training and sports, 2013; 17(9): 3-7. doi:10.15561/10.6084/ m9.figshare. 749686

2. Bogdanovs'ka NV. Influence of systemic physical loads on structural-functional changes of ventricles. Slobozhans'kij naukovo-sportivnij visnik, 2013;5:33-36. (in Ukrainian)

3. Bojchenko KIu. Study of female athletes' functional state with the help of new methodic approaches. Slobozhans'kij naukovo-sportivnij visnik, 2014;2:38-41. (in Ukrainian)

4. Vediaev FP, Demidov VA, Gaevskij IuG. Typological analysis of cardi-hemo-dynamic in boys and girls in relaxed state and under emotional tension. Fiziologiia cheloveka, 1990;16(6):113-118. (in Russian)

5. Getmancev S, Bogush V, Iacuns'kij O. Indicators of athletes' functional state in game kinds of sports.. Sportivnij visnik Pridniprov'ia, 2010;3:50-54. (in Ukrainian)

6. Dovganik MS, Chichkan OA, Strel'chenko VV, Iavors'kij OG. Changes in cardio-vascular system of men and women resulted from durable practicing of health related run. Slobozhans'kij naukovo-sportivnij visnik, 2014;2:76-79. (in Ukrainian)

7. Zapovitriana EB, Korobeynikov GV, Korobeinikova LG. Peculiarities of vegetative regulation of heart rate in wrestlers of different age groups. Pedagogics, psychology, medicalbiological problems of physical training and sports, 2015; 19(4): 22-26. doi:10.15561/18189172.2015.0404

8. Ivanova NV. Factors, determining functional state of cardio-respiratory system of athletes' specializing in cyclic kinds of sports. Slobozhans'kij naukovo-sportivnij visnik, 2013;5(38):108-111. (in Russian)

9. Levchenko V A. Indexes of hemodynamics in a dosage of physical activity in girls against the background of low systolic blood pressure. Pedagogics, psychology, medicalbiological problems of physical training and sports, 2015; 19(2): 43-46. doi:10.15561/18189172.2015.0207

10.Lisiak VM. Functional changes in organisms of women, practicing fitness-aerobic. Slobozhans 'kij naukovo-sportivnij visnik, 2014;3:53-56. (in Ukrainian)

11.Lisovs'kij B. Functional reserves of cardio-respiratory system as an indicator of human health. Visnik Prikarpats'kogo universitetu, 2006;2:31-34. (in Ukrainian)

12.Korkushko OV. Methods of analysis and age standards of heart rhythm's variability. Kiev; 2008. (in Russian)

13.Mikhajlov VM. Load-testing under control of ECG. Ivanovo; 2005. (in Russian)

14.Mickan BM, Popel' SL, Mickan MA. The methods of schoolchildren's physical condition, physical fitness, physical workability and somatic health research. IvanoFrankivsk; 2000. (in Ukrainian)

15.Bergamini C, Gambetti S, Dondi A, Cervellati C. Oxygen, Reactive Oxygen Species and Tissue Damage. Current Pharmaceutical Design. 20041;10(14):1611-26.

16.Bliznevsky AA, Kudryavtsev MD, Iermakov SS, Jagiello W. Formation of active-effective attitude of 12-13 years' judo athletes to sports functioning in competition period. Archives of Budo. 2016;12:101-15.

17.Bradley WJ, Morehen JC, Haigh J, Clarke J, Donovan TF, Twist C, et al. Muscle glycogen utilisation during Rugby match play: Effects of pre-game carbohydrate. Journal of Science and Medicine in Sport. 2016;19(12):1033-8.

18.Castillo D, Yanci J, Camara J, Weston M. The influence of soccer match play on physiological and physical performance measures in soccer referees and assistant referees. $J$ Sport Sci. 2016;34(6):557-63.

19.Crane J, Temple V. A systematic review of dropout from organized sport among children and youth. European Physical Education Review. 2015;21(1):114-31.

20.Dalen T, Ingvaldsen RP, Roaas TV, Pedersen AV, Steen I, Aune TK. The impact of physical growth and relative age effect on assessment inphysical education. European Journal of Sport Science. 2017;17(4):482-7.

21.Druz VA, Iermakov SS, Artemyeva GP, Puhach YI, Muszkieta R. Individualization factors of students' physical education at modern stage of its realization. Physical education of students, 2017; 21(1): 10-16. doi:10.15561/20755279.2017.0102

22.Druz VA, Iermakov SS, Nosko MO, Shesterova LYe, Novitskaya NA. The problems of students' physical training individualization. Pedagogics, psychology, medicalbiological problems of physical training and sports, 2017; 21(2): 4-12. doi:10.15561/18189172.2017.0201

23.Ebner A, Schillers H, Hinterdorfer P. Normal and pathological erythrocytes studied by atomic force microscopy. Methods mol. biol. 2011;736:223-241.

24.Ericsson I, Cederberg M. Physical activity and school performance: a survey among students not qualified for upper secondary school. Physical Education and Sport Pedagogy. 2015;20(1):45-66.

25.Fernandez-Balboa JM. Imploding the boundaries of transformative/critical pedagogy and research in physical education and sport pedagogy: looking inward for (self-) consciousness/knowledge and transformation. Sport Education and Society. 2017;22(4):426-41.

26.Gmiat A, Mieszkowski J, Prusik K, Prusik K, Kortas J, Kochanowicz A, et al. Changes in pro-inflammatory markers and leucine concentrations in response to Nordic Walking training combined with vitamin D supplementation in elderly women. Biogerontology 2017:1-14. doi:10.1007/s10522017-9694-8

27.Harper R, Vered KO. Developing communication as a graduate outcome: using 'Writing Across the Curriculum' as a whole-of-institution approach to curriculum and pedagogy. Higher Education Research \& Development. 2017;36(4):688-701.

28.Hastie PA, Wellhead T. Models-Based Practice in Physical Education: The Case for Sport Education. Journal of Teaching in Physical Education. 2016;35(4):390-9.

29.Haynes J, Miller J. Preparing pre-service primary school teachers to assess fundamental motor skills: two skills and two approaches. Physical Education and Sport Pedagogy. 2015;20(4):397-408.

30.Iermakov SS, Arziutov GN, Jagiello W. Quick training of students to judo techniques. Archives of Budo. 2016;12:1524.

31.Iermakov SS, Podrigalo LV, Jagiello W. Hand-grip strength as an indicator for predicting the success in martial arts athletes. Archives of Budo. 2016;12:179-86.

32.Ignat'eva SN, Kubasov RV. Metabolic adaptation resources of organism to studying at medical university students in european north. Annals of the Russian Academy of Medical Sciences, 2014;69(11-12):84-88. doi:10.15690/vramn. v69i11-12.1188 (in Russian)

33.Jastrzębski Z, Zychowska M, Jastrzębska M, Prusik K, Prusik K, Kortas J, et al. Changes in blood morphology and chosen biochemical parameters in ultra-marathon runners during a $100-\mathrm{km}$ run in relation to the age and speed of runners. Int J Occup Med Environ Health 2015;29(5):801814. doi:10.13075/ijomeh.1896.00610 
34.Jensen FB. The dual roles of red blood cells in tissue oxygen delivery: oxygen carriers and regulators of local blood flow. Journal of Experimental Biology. 2009;212(21):3387-93.

35.K. Abdelha MA, Abdelmotta S. Biochemical Changes of Hemoglobin and Osmotic Fragility of Red Blood Cells in High Fat Diet Rabbits. Pakistan Journal of Biological Sciences. 20101;13(2):73-7.

36.Khudolii OM, Ivashchenko OV, Iermakov SS, Rumba OG. Computer simulation of Junior gymnasts' training process. Science of Gymnastics Journal, 2016;8(3):215-228.

37.Kopeikina EN, Drogomeretsky VV, Kondakov VL, Kovaleva MV, Iermakov SS. Modification of harvard step-test for assessment of students' with health problems functional potentials. Physical Education of Students. 2016;20(4):4450. doi:10.15561/20755279.2016.0405

38.Kortas J, Kuchta A, Prusik K, Prusik K, Ziemann E, Labudda $S$, et al. Nordic walking training attenuation of oxidative stress in association with a drop in body iron stores in elderly women. Biogerontology 2017:1-8. doi:10.1007/s10522-0179681-0

39.Kortas J, Prusik K, Flis D, Prusik K, Ziemann E, Leaver $\mathrm{N}$. Effect of nordic walking training on iron metabolism in elderly women. Clin Interventions Aging, 2015;10:18891896. doi:10.2147/CIA.S90413

40.Kortas, J., Prusik, K., Flis, D., Prusik, K., Ziemann, E., Leaver, N., \& Antosiewicz, J. Re: Possible effect of decreased insulin resistance on ferritin levels after Nordic Walking training. Clin Interventions Aging 2016;11:150-151.

41.Kozina ZL, Iermakov SS, Kadutskaya LA, Sobyanin FI, Krzeminski M, Sobko IN, Ryepko OA. Comparative characteristic of correlation between pulse subjective indicators of girl students' and school girls' reaction to physical load. Physical Education of Students. 2016;20(4):2434. doi:10.15561/20755279.2016.0403

42.Lambert MI. General Adaptations-Exercise: Acute Versus Chronic and Strength Versus Endurance Training. Exercise and Human Reproduction. New York: Springer; 2016. doi:10.1007/978-1-4939-3402-7 6

43. Mahedero P, Calderon A, Arias-Estero JL, Hastie PA, Guarino AJ. Effects of Student Skill Level on Knowledge, Decision Making, Skill Execution and Game Performance in a MiniVolleyball Sport Education Season. Journal of Teaching in Physical Education. 2015;34(4):626-41.

44.Mairbäurl H. Red blood cells in sports: effects of exercise and training on oxygen supply by red blood cells. Frontiers in Physiology [Internet]. 2013 [cited 2017 May 13];4. Available from: http://journal.frontiersin.org/article/10.3389/ fphys.2013.00332/abstract

45.Malone S, Collins K. Relationship between individualized training impulse and aerobic fitness measures in hurling players across a training period. Journal of Strength and Conditioning Research. 2016;30(11):3140-5.

46. Matarrese P. Peroxynitrite induces senescence and apoptosis of red blood cells through the activation of aspartyl and cysteinyl proteases. The FASEB Journal [Internet]. 2004 Dec 13 [cited 2017 May 13]; Available from: http://www.fasebj. org/cgi/doi/10.1096/fj.04-2450fje

47.Mikhaylova LA. Central hemodynamics indices in senior pupils with increased educational and motive loading. Siberian Medical Review. 2013;3:55-58. doi:10.20333/250001362013-3-55-58

48.Miloski B, de Freitas VH, Nakamura FY, Nogueira FCD, Bara MG. Seasonal training load distribution of professional futsal players: effects on physical fitness, muscle damage and hormonal status. Journal of Strength and Conditioning Research. 2016;30(6):1525-33.

49.Mohanty JG, Nagababu E, Rifkind JM. Red blood cell oxidative stress impairs oxygen delivery and induces red blood cell aging. Frontiers in Physiology [Internet]. 2014 [cited 2017 May 13];5. Available from: http://journal. frontiersin.org/article/10.3389/fphys.2014.00084/abstract

50.Podrigalo LV, Galashko M N, Iermakov SS, Rovnaya OA, Bulashev AY. Prognostication of successfulness in armwrestling on the base of morphological functional indicators' analysis. Physical education of students, 2017; 21(1): 46-51. doi:10.15561/20755279.2017.0108

51.Serorez TB. Possibilities of increasing the physical health status of students different modes of racing loads. Pedagogics, psychology, medical-biological problems of physical training and sports, 2014; 18(4): 50-55. doi:10.6084/ m9.figshare. 950955

52. Wahl-Alexander Z, Curtner-Smith M, Sinelnikov O. Influence of a purposefully negotiated season of sport education on one teacher and his pupils. European Physical Education Review. 2016;22(4):450-64.

53.Zhu X. Student perspectives of grading in physical education. European Physical Education Review. 2015;21(4):409-420. doi:10.1177/1356336x15569628 


\section{Information about the authors:}

Popel' S.L.; http://orcid.org/0000-0002-2161-535X; serg_popel@mail.ru; Vasyl Stefanyk Precarpathian National University; 57 Shevchenko Str., Ivano-Frankivsk, 76018, Ukraine.

Tsap I.G.,; http://orcid.org/0000-0002-9698-0255; irasava-74@mail.ru; Vasyl Stefanyk Precarpathian National University; 57 Shevchenko Str., Ivano-Frankivsk, 76018, Ukraine.

Yatciv Ya.N.; http://orcid.org/0000-0003-2474-0401; yatsiv64@gmail.com; Vasyl Stefanyk Precarpathian National University; 57 Shevchenko Str., Ivano-Frankivsk, 76018, Ukraine.

Lapkovskyi E.Yi.; http://orcid.org/0000-0002-7717-2236; edlap@i.ua; Vasyl Stefanyk Precarpathian National University; 57 Shevchenko Str., Ivano-Frankivsk, 76018, Ukraine.

Synitsya A.V.; http://orcid.org/0000-0001-6608-919X; sinitciaav7@gmail.com; Vasyl Stefanyk Precarpathian National University; 57 Shevchenko Str., Ivano-Frankivsk, 76018, Ukraine.

Pjatnichuk D.V.; http://orcid.org/0000-0003-4668-9491; pdva@i.ua; Vasyl Stefanyk Precarpathian National University; 57 Shevchenko Str., Ivano-Frankivsk, 76018, Ukraine.

Cite this article as: Popel' SL, Tsap IG, Yatciv YaN, Lapkovsky EYi, Synitsya AV, Pyatnichuk DV. Special aspects of hemo-dynamic and reaction of erythrocytes in blood to standard physical load of different qualification female volleyball players. Pedagogics, psychology, medical-biological problems of physical training and sports, 2017;21(5):251-259. doi:10.15561/18189172.2017.0508 The electronic version of this article is the complete one and can be found online at: http://www.sportpedagogy.org.ua/index.php/PPS/issue/archive

This is an Open Access article distributed under the terms of the Creative Commons Attribution License, which permits unrestricted use, distribution, and reproduction in any medium, provided the original work is properly cited (http://creativecommons.org/licenses/by/4.0/deed.en).

Received: 11.05.2017

Accepted: 25.05.2017; Published: 25.09.2017 